\title{
Adapting Constant-volume Manometry for Studying Gas Exchange by Bulky Plant Organs
}

\author{
Amauri Alves Nery ${ }^{1}$ and Adonai Gimenez Calbo $^{2}$ \\ Centro Nacional de Pesquisa de Hortaliças, CP 0218, Brasília, DF 70359-970, Brazil \\ Additional index words. carbon dioxide, intercellular air volume, Ipomea batatas, Lycopersicon esculentum, oxygen, \\ porosity, Solanum tuberosum
}

\begin{abstract}
Constant-pressure manometry, previously designed to study $\mathrm{O}_{2}$ and $\mathrm{CO}_{2}$ gas exchange in small pieces of tissue, cells, and organelles, was adapted to study bulky organs. According to this new procedure, a near-zero-volume Devaux chamber connects a manometer to the internal atmosphere volume $\left(V_{G}\right)$ of a plant organ covered by a layer of epoxy, submerged in unstirred water, kept at constant temperature, and kept at the same $\mathrm{V}_{\mathrm{G}}$ pressure. Equations, based on $\mathrm{CO}_{2}$ and $\mathrm{O}_{2}$ solubility at equilibrium with $\mathrm{V}_{\mathrm{G}}$, were used to follow $\mathrm{O}_{2}$ consumption as a function of reduced internal $\mathrm{O}_{2}$ pressure over time [for organs with $V_{G}<0.1$ (v/v) and respiratory quotient (RQ) of 0.7 to 1.3] to observe the transition between aerobiosis and anaerobiosis and to measure $\mathrm{CO}_{2}$ evolution during the anaerobic phase. For those measurements, bulkyorgan manometry performed consistently in tomato $\left[V_{G}=6.41 \%(v / v)\right]$, sweetpotato $\left[V_{G}=8.57 \%(v / v)\right]$, and potato $\left[V_{G}\right.$ $=0.34 \%(\mathrm{v} / \mathrm{v})]$. The results indicate that constant-volume manometry is sufficiently precise to detect differences in respiratory metabolism as a function of intercellular $\mathrm{O}_{2}$ concentration in intact plant organs.
\end{abstract}

Constant-volume manometry has been used to study the consumption and production of gases such as $\mathrm{CO}_{2}, \mathrm{~N}_{2}$, and $\mathrm{O}_{2}$ during fermentation, photosynthesis, nitrate reduction, and protein decomposition and to study some specific respiratory enzymes (Burk and Milner, 1932). The equipment used for constant-volume manometry is constructed of a manometer with a rigid removable jar placed inside a temperature-controlled bath with shaking, to allow rapid equilibrium between the gas and liquid phases. According to this method, under constant temperature and volume, a change in the number of gas molecules can be followed by measuring pressure (Umbreit et al., 1972). Perkins (1943) described three main types of manometry equipment. The first was a constant-volume Warburg-Bancroft respirometer. The second was a differential respirometer in which the side of the manometer, which is usually open to the air, is connected to another closed jar to eliminate small errors caused by temperature and barometric changes during the assay. The third, used with the WarburgBarcroft equipment, allows direct and differential manometric measurements.

Several methods were developed to extract and evaluate the intercellular concentrations of different gaseous components such as $\mathrm{CO}_{2}$, ethylene, $\mathrm{O}_{2}$, and $\mathrm{N}_{2}$ from bulky organs. The main principles used for the extraction techniques are the concentration equilibrium between the gaseous components of an internal chamber (Wardlaw and Leonard, 1939) or an external chamber (Devaux, 1891) and the plant internal atmosphere. In addition, there are several vacuum-extraction techniques (Burton and Spragg, 1950; Calbo and Sommer, 1987; Magness, 1922) that also have been used to measure porosity or $\mathrm{V}_{\mathrm{G}}$ (Burton and Spragg, 1950; Calbo and Sommer, 1987). In the case of porosity measurements, other principles such as pycnometry (Jensen et al., 1969) and inert gases (Cameron and Yang, 1982) have also been used. For concentration measurements of very small gaseous samples with $\mathrm{CO}_{2}, \mathrm{O}_{2}$, and

Received for publication 12 Aug. 1992. Accepted for publication 4 May 1994. This investigation was supported by research grants from the Brazilian Scientific and Technological Council (CNPq). We are indebted to Linda Styer Caldas and Washington L.C. Silva for their critical reading of the manuscript. The cost of publishing this paper was defrayed in part by the payment of page charges. Under postal regulations, this paper therefore must be hereby marked advertisement solely to indicate this fact.

${ }^{1}$ Research assistant.

${ }^{2}$ Researcher
$\mathrm{N}_{2}$, the method of Bonnier and Mangin (Thoday, 1913), or one of its adaptations such as the one made by Scholander (1947), is reliable and inexpensive.

The main objective of this work was to present an extension of the Warburg-Bancroft technique to apply constant-volume manometry to bulky organs using a new approach to achieve equilibrium between the liquid and the gas phases in plant organs sealed in a vessel maintained at a constant temperature and volume. Bulky-organ manometry was evaluated as a tool to study respiration as a function of intercellular $\mathrm{O}_{2}$ partial pressure and anaerobic $\mathrm{CO}_{2}$ evolution.

\section{Theory}

Assumptions. The basic assumptions of this work are that 1) the volume of an externally sealed organ remains constant during the measurement; 2) the equilibrium between the gas and the liquid phase inside the organ is very rapid and, consequently, changes in the liquid phase can be followed in the gas phase; 3) changes of the internal gradients of $\mathrm{O}_{2}$ and $\mathrm{CO}_{2}$ at the intercellular level are not a limiting factor to the method; and 4 ) the half-time in seconds $\left(\mathrm{t}_{1 / 2}\right)$ for equilibrium between the pressure-measuring device with nearzero volume and the internal atmosphere is small and can be disregarded.

Aerobic phase. The total number of gas molecules $\left(\mathrm{n}_{\mathrm{T}}\right)$ inside an externally sealed bulky organ at constant temperature can be represented as the sum of its components:

$$
\mathrm{n}_{\mathrm{T}}=\mathrm{n}_{\mathrm{O}_{2}}+\mathrm{n}_{\mathrm{CO}_{2}}+\mathrm{n}_{\mathrm{N}_{2}}+\mathrm{n}_{\mathrm{Ar}}+\ldots
$$

where $\mathrm{n}$ is the number of moles of each specified gas molecule.

Assuming that for each molecule of $\mathrm{O}_{2}$ consumed one molecule of $\mathrm{CO}_{2}$ is released (or the converse) and that $\mathrm{N}_{2}, \mathrm{Ar}, \mathrm{H}_{2} \mathrm{O}$, and all minor components of the air can be disregarded for calculations of $\mathrm{CO}_{2}$ and $\mathrm{O}_{2}$ exchange, then $\mathrm{n}_{\mathrm{T}}$ could be represented by

$$
\mathrm{n}_{\mathrm{T}}=\left(\mathrm{n}_{\mathrm{O}_{2}}+\mathrm{n}_{\mathrm{CO}_{2}}\right)_{\mathrm{L}}+\left(\mathrm{n}_{\mathrm{O}_{2}}+\mathrm{n}_{\mathrm{CO}_{2}}\right)_{\mathrm{G}}
$$

where the subscripts $\mathrm{L}$ and $\mathrm{G}$ are the liquid and gas phases, respectively.

Substituting the number of molecules of each species by the product of the concentration $\left(\mathrm{mol} \cdot \mathrm{liter}^{-1}\right)$ and the volume of the 
system (V) in liters, Eq. [3] is obtained:

$$
\mathrm{n}_{\mathrm{T}}=\mathrm{V}_{\mathrm{L}}\left(\left[\mathrm{O}_{2}\right]+\left[\mathrm{CO}_{2}\right]\right)_{\mathrm{L}}+\mathrm{V}_{\mathrm{G}}\left(\left[\mathrm{O}_{2}\right]+\left[\mathrm{CO}_{2}\right]\right)_{\mathrm{G}}
$$

The ideal gases could be rewritten for $\mathrm{CO}_{2}$ and $\mathrm{O}_{2}$ as follows:

$$
\begin{aligned}
& \mathrm{PV}=\mathrm{nRT} \\
& {\left[\mathrm{O}_{2}\right]_{\mathrm{G}}=\mathrm{p}_{\mathrm{O}_{2}} / \mathrm{RT}} \\
& {\left[\mathrm{CO}_{2}\right]_{\mathrm{G}}=\mathrm{p}_{\mathrm{CO}_{2}} / \mathrm{RT}}
\end{aligned}
$$

where $\mathrm{P}$ is the partial pressure $(\mathrm{kPa}), \mathrm{R}$ is the gas constant $(8.3143$ $\mathrm{J} \cdot \mathrm{K}^{-1} \cdot \mathrm{mol}^{-1}$ ), and $\mathrm{T}$ is the temperature.

Substituting Eqs. [4] and [6] into Eq. [3] generates

$$
\mathrm{n}_{\mathrm{T}}=\mathrm{V}_{\mathrm{L}}\left(\left[\mathrm{O}_{2}\right]_{\mathrm{L}}+\left[\mathrm{CO}_{2}\right]_{\mathrm{L}}\right)+\mathrm{V}_{\mathrm{G}}\left[\left(\mathrm{p}_{\mathrm{O}_{2}} / \mathrm{RT}\right)+\left(\mathrm{p}_{\mathrm{CO}_{2}} / \mathrm{RT}\right)\right]
$$

The concentrations of $\mathrm{O}_{2}$ and $\mathrm{CO}_{2}$ in the liquid phase can be calculated knowing that $\alpha_{\mathrm{O}_{2}}$ and $\alpha_{\mathrm{CO}_{2}}$ are the solubilities of $\mathrm{O}_{2}$ and $\mathrm{CO}_{2}$ in water at normal pressure (mol-liter ${ }^{-1}$ ) (Armstrong, 1979; Umbreit et al., 1972).

$$
\begin{aligned}
& {\left[\mathrm{O}_{2}\right]_{\mathrm{L}}=\alpha_{\mathrm{O}_{2}} \mathrm{p}_{\mathrm{O}_{2}}} \\
& {\left[\mathrm{CO}_{2}\right]_{\mathrm{L}}=\alpha_{\mathrm{CO}_{2}} \mathrm{p}_{\mathrm{CO}_{2}}}
\end{aligned}
$$

An expression relating pressure variation and $\mathrm{O}_{2}$ consumption can then be obtained by substituting Eqs. [8] and [9] into Eq. [7]:

$\mathrm{n}_{\mathrm{T}}=\mathrm{p}_{\mathrm{CO}_{2}}\left(\alpha_{\mathrm{CO}_{2}} \mathrm{~V}_{\mathrm{L}}+\mathrm{V}_{\mathrm{G}} / \mathrm{RT}\right)+\mathrm{p}_{\mathrm{O}_{2}}\left(\alpha_{\mathrm{O}_{2}} \mathrm{~V}_{\mathrm{L}}+\mathrm{V}_{\mathrm{G}} / \mathrm{RT}\right)$

Separating $\mathrm{p}_{\mathrm{CO}_{2}}$ from Eq. [10] yields

$$
\mathrm{p}_{\mathrm{CO}_{2}}=\left[\mathrm{n}_{\mathrm{T}}-\mathrm{p}_{\mathrm{O}_{2}}\left(\alpha_{\mathrm{O}_{2}} \mathrm{~V}_{\mathrm{L}}+\mathrm{V}_{\mathrm{G}} / \mathrm{RT}\right)\right] /\left(\alpha_{\mathrm{CO}_{2}}+\mathrm{V}_{\mathrm{G}} / \mathrm{RT}\right)
$$

The sum of partial pressures of $\mathrm{O}_{2}$ and $\mathrm{CO}_{2}(\mathrm{H})$ could be expressed as

$$
\mathrm{H}=\mathrm{p}_{\mathrm{O}_{2}}+\mathrm{p}_{\mathrm{CO}_{2}}
$$

Substituting $\mathrm{p}_{\mathrm{CO}_{2}}$ from Eq. [11] into Eq. [12] gives

$$
\mathrm{p}_{\mathrm{CO}_{2}}=\left[\mathrm{H}\left(\alpha_{\mathrm{CO}_{2}} \mathrm{~V}_{\mathrm{L}}+\mathrm{V}_{\mathrm{G}} / \mathrm{RT}\right)-\mathrm{n}_{\mathrm{T}]}\right] /\left[\mathrm{V}_{\mathrm{L}}\left(\alpha_{\mathrm{O}_{2}}-\alpha_{\mathrm{CO}_{2}}\right)\right]
$$

Differentiating Eq. [13] with relation to $\mathrm{H}$ gives

$$
\mathrm{dp}_{\mathrm{O}_{2}} / \mathrm{dH}=\left(\alpha_{\mathrm{CO}_{2}}+\mathrm{V}_{\mathrm{G}} / \mathrm{V}_{\mathrm{L}} \mathrm{RT}\right) /\left(\alpha_{\mathrm{O}_{2}}-\alpha_{\mathrm{CO}_{2}}\right)
$$

Equation [14] represents the change in $\mathrm{P}_{\mathrm{O}_{2}}$ as a function of the pressure change measured in the sealed organ.

Anaerobic phase. In the anaerobic phase, $\mathrm{n}_{\mathrm{T}}$ is no longer constant and its variation is a function of $\mathrm{CO}_{2}$ production. In this particular case, the pressure variation is a measurement of $\mathrm{dn}_{\mathrm{CO}_{2}}$ :

$$
\mathrm{dn}_{\mathrm{CO}_{2}}=\mathrm{V}_{\mathrm{G}} \mathrm{d}\left[\mathrm{CO}_{2}\right]_{\mathrm{G}}+\mathrm{V}_{\mathrm{L}} \mathrm{d}\left[\mathrm{CO}_{2}\right]_{\mathrm{L}}
$$

Under anaerobiosis, $d p_{\mathrm{O}_{2}}=0$ (Eq. [12]) and $\mathrm{dp}_{\mathrm{CO}_{2}}$ is $\mathrm{dH}$. Substituting Eqs. [6] and [9] into [15] gives

$$
\mathrm{dn}_{\mathrm{CO}_{2}}=\left(\alpha_{\mathrm{CO}_{2}} \mathrm{~V}_{\mathrm{L}}+\mathrm{V}_{\mathrm{G}} / \mathrm{RT}\right) \mathrm{dp}_{\mathrm{CO}_{2}}
$$

Assumption 1. The constancy of the sealed bulky-organ volume $\left(\mathrm{V}_{\mathrm{o}}\right)$ is a requirement for using the constant-volume manometry method. Assume then the behavior of a sealed organ enclosed within an incompressible chamber filled with water at constant temperature (Fig. 1a) so that

$$
\Delta \mathrm{V}_{\mathrm{t}}=\Delta \mathrm{V}_{\mathrm{o}}+\Delta \mathrm{V}_{\mathrm{w}}
$$

$$
\begin{aligned}
& \Delta \mathrm{V}_{\mathrm{o}}=\Delta \mathrm{V}_{\mathrm{G}}+\Delta \mathrm{V}_{\mathrm{SL}} \\
& \Delta \mathrm{V}_{\mathrm{w}}=\Delta \mathrm{V}_{\mathrm{SL}}
\end{aligned}
$$

Since the organ is sealed and the expected variations of solids and liquids $\left(\mathrm{V}_{\mathrm{SL}}\right)$ are small because there is no net influx of water $\left(\mathrm{V}_{\mathrm{w}}\right)$, then $\mathrm{V}_{\mathrm{SL}}$ could be ignored. Accordingly, the variation of $\mathrm{V}_{\mathrm{G}}$ will be equal to the total system volume variation $\left(\mathrm{V}_{\mathrm{t}}\right)$, which is zero due to chamber incompressibility. Consequently, a pressure equilibrium among the measured pressure $(\mathrm{H})$, organ pressure $\left(\mathrm{p}_{\mathrm{o}}\right)$, and liquid pressure $\left(\mathrm{p}_{\mathrm{L}}\right)$ should be sustained (Eq. [20]):

$$
\mathrm{H}=\mathrm{p}_{\mathrm{o}}=\mathrm{p}_{\mathrm{L}}
$$

Equation [20] describes the sufficient condition that can be used to set up alternative systems even without using undeformable recipients (Fig. 1b).

Assumption 2. The $\mathrm{O}_{2}$ and $\mathrm{CO}_{2}$ equilibrium rate between the liquid and gas phase inside the organ is fundamental in this method, as it is in the Warburg-Bancroft respirometer. Perkins (1943) stressed the necessity of a good shaker to accelerate this equilibrium. In the present work, diffusion plays a larger role than shaking to accelerate the equilibrium, since no mechanical shaker can be used inside the organ.

The mentioned reasons indicate that it is important to know the time required by a front of gas molecules, located at a volume element between two cell walls, to reach the protoplast. Figure 2A shows a section through the plant tissue with a gas volume between two cell walls. Considering that initially $(\mathrm{t}=0)$ all $\mathrm{O}_{2}$ molecules are in this volume element, then Eq. [21] derived from Ficks's second law can be used to estimate the time intervals $t_{1}$ and $t_{2}$ expended for a fraction 1/e of the molecules to travel a distance equal to or larger than $x_{1}$ and $x_{2}$ within the cell.

$$
\overline{\mathrm{x}}^{2}=4 \mathrm{Di} \cdot \mathrm{t}
$$

where $\bar{x}$ is the average distance traveled by the molecules, Di is the diffusion coefficient, and $t$ is the time expended by the molecular front.

Using Eq. [21] requires that all $\mathrm{O}_{2}$ molecules be lined in the orthogonal plane that contains $\mathrm{X}_{0}$; this is not the situation in Fig. 2 . However, since the Di for an $\mathrm{O}_{2}$ molecule in air $\left(0.207 \mathrm{~cm}^{2} \cdot \mathrm{s}^{-1}\right)$ is $\approx 10^{4}$ times larger than in water $\left(2.38 \times 10^{-5} \mathrm{~cm}^{2} \cdot \mathrm{s}^{-1}\right)$ at $25 \mathrm{C}$ (Armstrong, 1979), the $\mathrm{V}_{\mathrm{G}}$ could be considered an extremely thin layer.

An estimation of the time to reach equilibrium between $\mathrm{V}_{\mathrm{G}}$ and the protoplast of the cells can be obtained by applying Eq. [21] with two initial conditions.

a) It is assumed that cyclosis stirs the cytoplasm efficiently and the only resistance to diffusion is located at the cell wall water layer (Fig. 2A). If the average thickness of the cell wall is $\approx 10 \mu \mathrm{m}$ (Nobel, 1970), then the average time for $1 / \mathrm{e}_{2}$ molecules to cross the cell wall according to Eq. [21] is $1.0 \times 10^{-4} \mathrm{sec}$.

b) It is assumed that the cytoplasm of those cells remains inert (Fig. $2 b)$. Under this condition, the time for diffusion of 1/e of the $\mathrm{O}_{2}$ molecules from the $\mathrm{V}_{\mathrm{G}}$ at the initial position $\mathrm{x}_{0}=0$ to a point located at $\mathrm{x}_{1}=100 \mu \mathrm{m}$ apart is $1.0 \times 10^{-2} \mathrm{sec}$.

These estimates suggest that all cells may almost be in equilibrium with the $\mathrm{V}_{\mathrm{G}}$ in their vicinity.

Assumption 3. Changes of the internal gradients of $\mathrm{O}_{2}$ and $\mathrm{CO}_{2}$ at the intercellular level should not be a limiting factor because the Devaux chamber (Fig. 3) closely approximates the average com- 


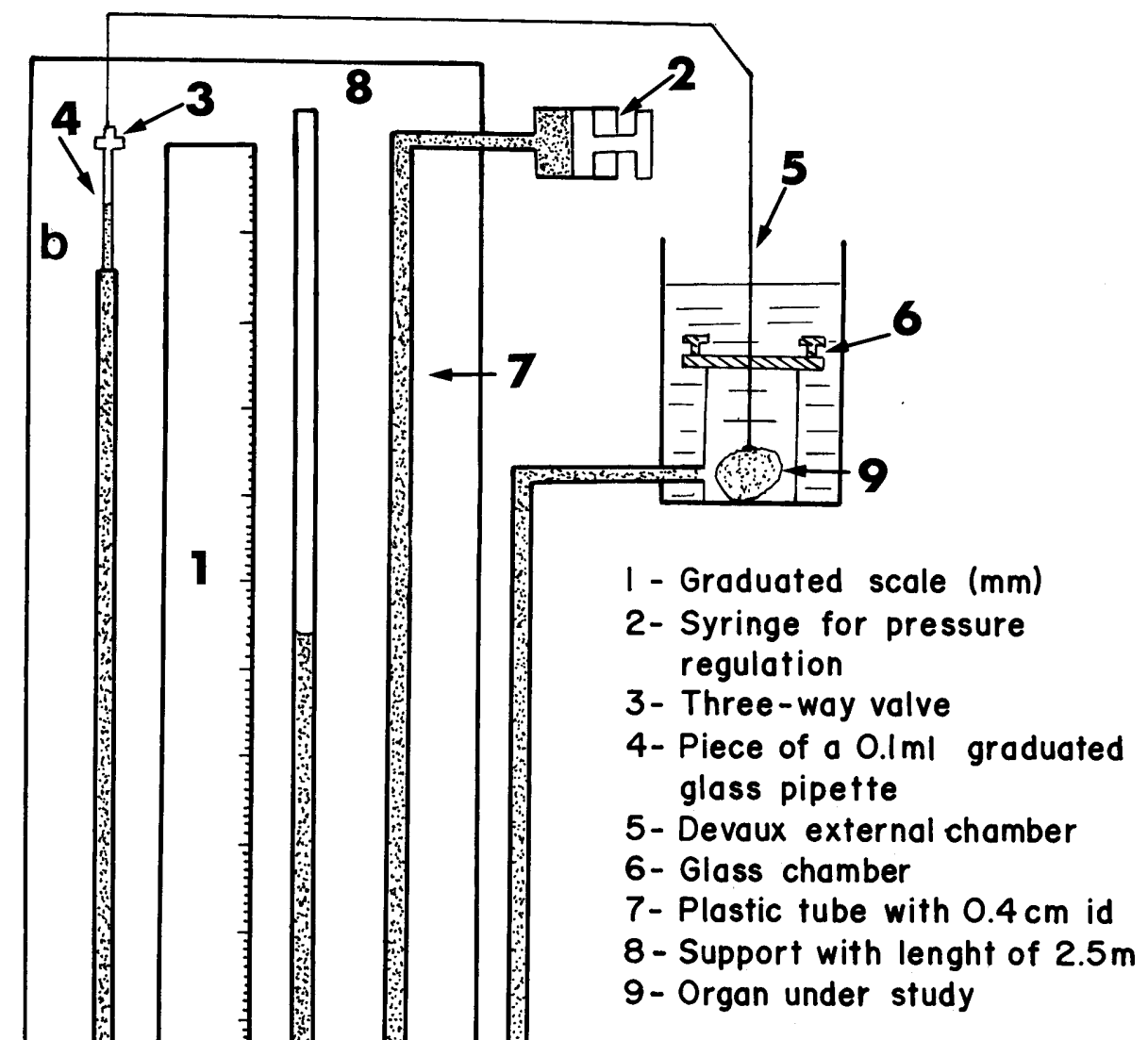

1 - Graduated scale $(\mathrm{mm})$

2- Syringe for pressure regulation

3- Three-way valve

4- Piece of a $0.1 \mathrm{ml}$ graduated glass pipette

- Devaux external chamber

- Glass chamber

$m$ id

- Support with lenght of $2.5 \mathrm{~m}$

a

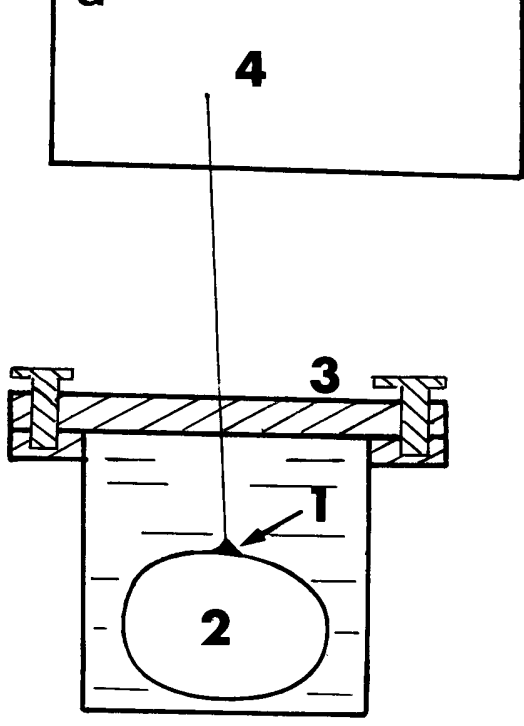

1 - Pressure transducer

2- Organ under study

3- Incompressible chamber.

4 -Potentiometric register

Fig. 1. Equipment to measure aerobic $\mathrm{O}_{2}$ and anaerobic $\mathrm{CO}_{2}$ evolution of a sealed bulky organ $(2,9)$ kept inside a chamber filled with water $(3,6)$ using constant-volume manometry. (a) Alternative electronic system that could be also used to apply the constant-volume manometry technique, with the bulky organ kept inside an incompressible chamber. In this automated model, the Devaux chamber is replaced by a pressure transducer (1) sealed against the organ (2) and connected to an XY potentiometer (4) that should register the pressure changes in time with an accuracy of at least $50 \mathrm{~Pa}$. (b) The intercellular air pressure is followed in a millimetric 2.5-m U-shaped manometer (1) filled with water connected to the organ (9) by a Devaux chamber with near-zero dead volume (5). The manometer column height is slowly changed in time with a syringe (2) to keep the air volume constant, as shown by the water level (4). 

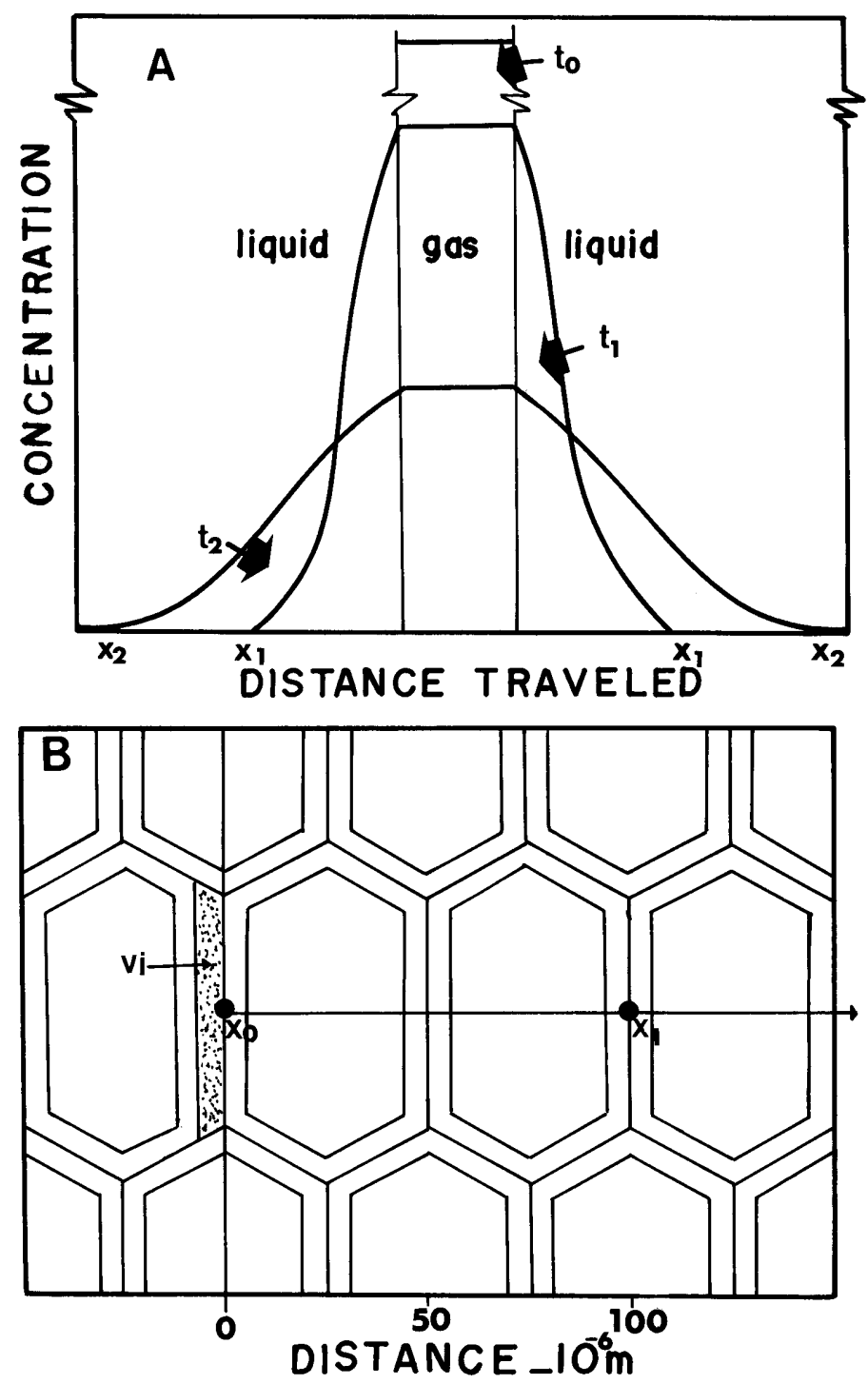

Fig. 2. Unidirectional $\mathrm{O}_{2}$ diffusion models. (A) Oxygen random distribution from an intercellular air volume $\left(\mathrm{V}_{\mathrm{i}}\right)$ located between two cell walls. $\mathrm{X}_{1}$ and $\mathrm{X}_{2}$ are the distances traveled by the molecular front after the time intervals $t_{1}$ and $t_{2}\left(t_{2}=10 t_{1}\right)$ and the ordinate is the local concentration. (B) Diagram of a transversal section showing $\mathrm{V}_{\mathrm{i}}$ and a $100-\mu \mathrm{m} \mathrm{O}_{2}$ path between $\mathrm{X}_{0}$ and $\mathrm{X}_{1}$ within the plant tissue.

position for those organs (Cameron, 1982). Furthermore, it can be hypothesized that, for the sealed organ under study, the internal gradients will vanish during the measurement. From those considerations, it is assumed that, even for organs without a clear superficial barrier to diffusion, the internal gradients of concentration should not limit the use of this manometric technique.

Assumption 4. For constant-volume manometry of bulky organs, the gaseous composition of the near-zero dead-volume Devaux chamber that connects the organ and the pressure-measuring device should be in equilibrium with $\mathrm{V}_{\mathrm{G}}$ (Fig. 3a).

Assuming that a Devaux chamber with a volume $\mathrm{V}_{\mathrm{C}}$ is loosing $\mathrm{O}_{2}$ to an organ at rate $\mathrm{J}\left(\mathrm{mol} \cdot \mathrm{s}^{-1}\right)$, with the time in seconds and $\mathrm{n}_{\mathrm{C}}$ the number of $\mathrm{O}_{2}$ molecules in the chamber, the changes of $n_{C}$ in time can be expressed by Eq. [22]:

$$
\text { Jdt }=\operatorname{dn}_{\mathrm{C}}
$$

Since $\mathrm{J}$ is proportional to the concentration gradient between the internal atmosphere $\left(c_{i}\right)$ and the Devaux chamber $\left(c_{C}\right)\left(\right.$ mol $_{1}$ liter $\left.{ }^{-1}\right)$ and is inversely related to the diffusion resistance $(\phi)$ of the region of the organ in contact with the Devaux chamber, Eq. [22] can be rewritten as

$\left(c_{i}-c_{C}\right) d t / \phi=V_{c} d_{c}$

or in its integral form as

$-\mathrm{t} / \phi \mathrm{V}_{\mathrm{c}}=\operatorname{Ln}\left(\mathrm{c}_{\mathrm{i}}-\mathrm{c}_{\mathrm{c}}\right)$

From Eq. [24], it can be shown that

$$
\mathrm{t}_{1 / 2}=-\mathrm{V}_{\mathrm{c}} \phi \operatorname{Ln}_{1 / 2}
$$

where $t_{1 / 2}$ is the time it takes for the Devaux chamber to reach half of the internal organ concentration.

The unit of $\phi_{\mathrm{o}}$ is liters $\cdot \mathrm{s}^{-1}$, which is convenient since the average difference in $\mathrm{O}_{2}$ concentration between the internal atmosphere and the air divided by the rate of consumption, an average resistance or transforming factor, is available in the literature for many organs and can be expressed as liters $\cdot \mathrm{kg}^{-1} \cdot \mathrm{s}^{-1}$. As a consequence, this transforming factor divided by the specific organ mass estimates the organ diffusion resistance $(\phi)$.

Fick's first law of proportionality between the cross-section area and the flux can be used to show that

$$
\phi=\phi_{\mathrm{o}} \mathrm{A}_{\mathrm{o}} / \mathrm{A}_{\mathrm{c}}
$$

where $\phi$ is the whole-organ diffusion resistance, $A_{o}$ is the organ external area $\left(\mathrm{cm}^{2}\right)$, and $A_{c}$ is the Devaux chamber area.

According to Eqs. [25] and [26], $\mathrm{t}_{1 / 2}$ will become smaller as the Devaux chamber area $\mathrm{A}_{\mathrm{c}}$ grows bigger and $\mathrm{V}_{\mathrm{c}}$ gets smaller.

\section{Materials and Methods}

Plant material. Tuberous roots of 'Coquinho' sweetpotato [Ipomea batatas (L.) Lam], 'Bintje' potato tubers (Solanum tuberosum L.), and 'Kada' tomato (Lycopersicon esculentum Mill.) grown at Centro Nacional de Pesquisa de Hortaliças, Brasília, Brazil, were stored at $13 \pm 2 \mathrm{C}$ for $\approx 40$ days, $9 \pm 2 \mathrm{C}$ for $\approx 20$ days, and $20 \pm 3 \mathrm{C}$ for 1 day, respectively. Organs were transferred to the exact assay temperature 1 day before each measurement to achieve a steady-state temperature.

Devaux chamber. A chamber was placed at the surface of the organ that had a smaller resistance to diffusion in an area abraded $24 \mathrm{~h}$ before with a sharp razor blade to work as an extension of the $\mathrm{V}_{\mathrm{G}}$ in dynamic equilibrium conditions (Devaux, 1891) (Fig. 3). The Devaux chamber was reduced to a slightly curved copper plate with a 1- to $3-\mathrm{cm}^{2}$ (potatoes and sweetpotatoes) and a circular copper plate for tomatoes with a $0.18-\mathrm{mm}-\mathrm{i} . \mathrm{d}$. plastic capillary inserted in its center for gas sampling with a hypodermic syringe. The surface of the chamber had a coarse texture to avoid air blockage by the contact between the chamber and the organ. This chamber was fixed to the organ with araldite.

Manometer. The Devaux chamber (Fig. 1b, 5), with a capillary in its center, was connected to the organ (Fig. 1b, 9) and the manometer through the three-way valve (Fig. 1b, 3). To reduce the system's air volume (Fig. 1b, 4), a small piece of a 0.1-ml glass pipette was set on the tip of the plastic manometer tube. The threeway valve (Fig. 1b, 3) is used to connect the organ to the air and the manometer and to align it with the scale. During operation, the system pressure is changed with a syringe (Fig. 1b, 2) by adding or removing water in the manometer when the water meniscus departs from its origin in this pipette.

Alternative $\mathrm{CO}_{2}$ and $\mathrm{O}_{2}$ measurements. After allowing time for equilibrium between the gaseous components of the internal atmosphere and the Devaux chamber attached to a nonsealed organ (Eq. [25]), 0.1-ml gas samples were withdrawn from the chamber 
using a 1-ml syringe with near-zero dead volume. The concentrations of $\mathrm{CO}_{2}$ and $\mathrm{O}_{2}$ were measured with the Bonnier-Mangin microtechnique (Scholander, 1947; Thoday, 1913).

Operation. The organ, with the Devaux chamber attached, was completely covered with araldite and enclosed in the chamber (Fig. 1b, 6). The chronometer is started when the three-way valve position is changed to connect the manometer and the organ internal atmosphere through the Devaux chamber. With small movements of the syringe (Fig. 1b, 2) the meniscus was adjusted a millimeter below (for aerobic $\mathrm{O}_{2}$ consumption) or above (for anaerobic $\mathrm{CO}_{2}$ evolution) the zero at the pipette in the left arm of the manometer. The height in the right arm was then recorded. At the exact moment that the meniscus went back to zero, the corresponding time was also recorded. The height increments used in this feedback process should not be $>2.0 \mathrm{~cm}$ due to the time required for equilibrium between the Devaux chamber pressure and the organ internal atmosphere pressure.

The presented curves relating the rate of $\mathrm{O}_{2}$ consumption or $\mathrm{CO}_{2}$ evolution vs. time and $\mathrm{O}_{2}$ evolution vs. internal $\mathrm{O}_{2}$ partial pressure represent data from at least five consecutive experiments.

A reliable electronic feedback mechanism could be used with a pressure transducer (Fig. 1a) to automate this process.

Intercellular gas determinations. $\mathrm{V}_{\mathrm{G}}$ was estimated with a semipycnometric method (Calbo and Nery, 1994).

The internal $\mathrm{O}_{2}$ partial pressure was estimated backwards, knowing that at the point of transition between aerobiosis and anaerobiosis the intercellular $\mathrm{O}_{2}$ partial pressure is near zero

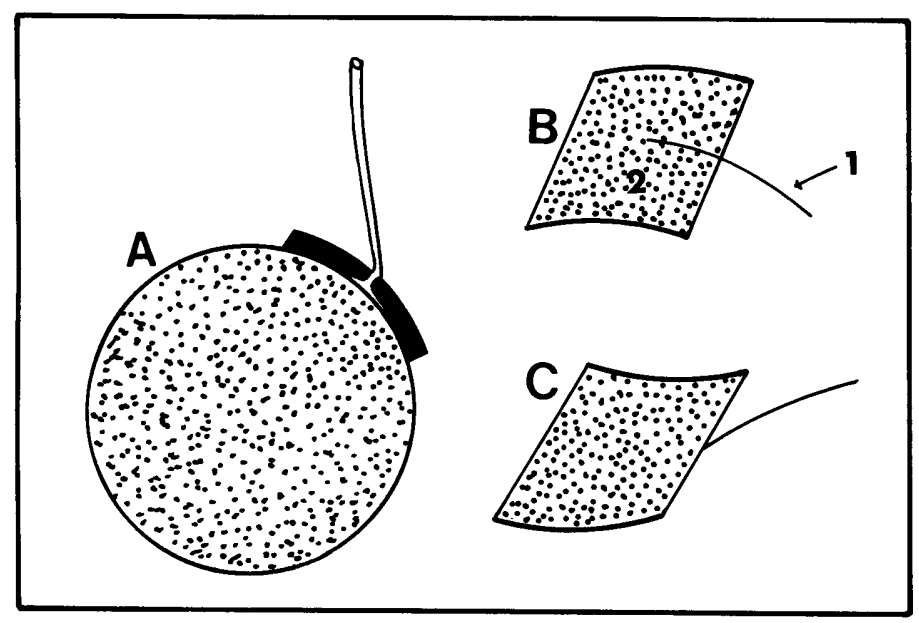

Fig. 3. Devaux external chamber with near-zero dead volume connected to the organ surface by a sealant to work as an extension of the internal organ atmosphere. This chamber was used to take internal atmosphere gas samples and connect the plant organ to the manometer for constant-volume manometry. $\mathrm{A}=$ Devaux external chamber connected to the organ. $\mathrm{B}=$ top view. $\mathrm{C}=$ underneath view, 1 = copper capillary, 2 = slightly curved copper plate.
(Beevers, 1961; Yocum and Hanckett, 1957). The initial internal concentration could either be measured in samples taken from the Devaux external chamber or directly estimated from the manometric reading (Table 1 ).

The $\mathrm{O}_{2}$ consumption rate $\left(\mathrm{mol} \cdot \mathrm{kg}^{-1} \cdot \mathrm{h}^{-1}, \mathrm{R}_{\mathrm{O}_{2}}\right)$ was obtained with Eq. [27]:

$$
\mathrm{R}_{\mathrm{O}_{2}}=\left(\alpha_{\mathrm{O}_{2}} \mathrm{~V}_{\mathrm{L}}+\mathrm{V}_{\mathrm{G}} / \mathrm{RT}\right) \mathrm{dp}_{\mathrm{O}_{2}} \mathrm{M}_{\mathrm{o}} \mathrm{dt}
$$

and the rate of $\mathrm{CO}_{2}$ evolution $\left(\mathrm{mol} \cdot \mathrm{kg} \cdot \mathrm{h}^{-1}, \mathrm{R}_{\mathrm{CO}_{2}}\right.$ ) was obtained with Eq. [28]:

$$
\mathrm{R}_{\mathrm{CO}_{2}}=\left(\alpha_{\mathrm{CO}_{2}} \mathrm{~V}_{\mathrm{L}}+\mathrm{V}_{\mathrm{G}} / \mathrm{RT}\right) \mathrm{dp}_{\mathrm{CO}_{2}} \mathrm{M}_{\mathrm{o}} \mathrm{dt}
$$

where $\mathrm{V}_{\mathrm{L}}$ was estimated as the volume of the organ minus its gaseous volume and Mo is the organ mass $(\mathrm{kg})$.

\section{Results and Discussion}

Carbon dioxide evolution, $V_{G} / V_{L}$, and $R Q$ effects. Figure 4 shows the maximum theoretical $\mathrm{CO}_{2}$ pressure developed when all $\mathrm{O}_{2}$ molecules contained inside an organ having an initial internal $\mathrm{O}_{2}$ pressure of $20 \mathrm{kPa}$ are consumed in respiration, with an RQ of 1 and an initial $\mathrm{CO}_{2}$ pressure of $0.0 \mathrm{kPa}$ as a function of the $\mathrm{V}_{\mathrm{G}} / \mathrm{V}_{\mathrm{L}}$ (Eq. [29]).

$$
\mathrm{p}_{\mathrm{CO}_{2}}=\mathrm{RTn}_{\mathrm{T}} /\left(\mathrm{RT} \alpha_{\mathrm{CO}_{2}} \mathrm{~V}_{\mathrm{L}}+\mathrm{V}_{\mathrm{G}}\right)
$$

The maximum $\mathrm{CO}_{2}$ pressure developed during aerobic respiration increases as a function of $\mathrm{V}_{\mathrm{G}} / \mathrm{V}_{\mathrm{L}}$ and becomes asymptotic to 20 $\mathrm{kPa}$, as $\mathrm{V}_{\mathrm{G}} / \mathrm{V}_{\mathrm{L}}$ tends to be infinite (Fig. 4). If $\mathrm{V}_{\mathrm{G}} / \mathrm{V}_{\mathrm{L}}$ is very large, $\mathrm{p}_{\mathrm{CO}_{2}}$ becomes equal to the initial $\mathrm{p}_{2}$ and the total pressure variation becomes null. Consequently, this method could no longer be applied. Thus, organs having $\mathrm{V}_{\mathrm{G}} / \mathrm{V}_{\mathrm{L}}<0.5$ and usually $<0.1$ are suitable for use with this manometric technique. Accordingly, for bulky organs having $\mathrm{V}_{\mathrm{G}} / \mathrm{V}_{\mathrm{L}}<0.1(\mathrm{v} / \mathrm{v})$, $\mathrm{dH}$ should estimate $\mathrm{dp}_{\mathrm{O}_{2}}$ with an error $<2.5 \%$.

Equation [29] can also be used to estimate the errors caused by RQ values different from 1. For this purpose, the right side of Eq. [29] has to be multiplied by RQ. Using this procedure, it can be proved that, for $0.7<\mathrm{RQ}<1.3$, the errors in the estimated $\mathrm{O}_{2}$ consumption rate are negligible for $\mathrm{V}_{\mathrm{G}} / \mathrm{V}_{\mathrm{L}}<0.1$.

Respiration and intercellular $\mathrm{O}_{2}$. Constant-volume manometry of bulky organs can be used efficiently to measure respiration as a function of the internal $\mathrm{O}_{2}$ partial pressure in organs, such as roots, tubers, and fruit, with variable $\mathrm{V}_{\mathrm{G}}$ and firmness (Fig. 5). These respiration rates were similar to standard chromatographic estimates of $\mathrm{CO}_{2}$ evolution in organs for which RQ is presumably close to the unit (Table 1).

The manometric method can even be used to estimate the cytochrome oxidize apparent $\mathrm{Km}$ for organs with very low respiration rate and a nearly null $\mathrm{CO}_{2}$ evolution rate in the anaerobic

Table 1. Estimates ${ }^{\mathrm{z}}$ of intercellular $\mathrm{O}_{2}$ pressure reduction obtained by manometry and using the Devaux external chamber method, intercellular air

\begin{tabular}{|c|c|c|c|c|c|c|}
\hline \multirow{3}{*}{$\frac{\text { Organ }}{\text { Potato }}$} & \multirow{2}{*}{$\begin{array}{c}\text { Pressure } \\
\text { reduction } \\
(\mathrm{kPa}) \text { at } \mathrm{O}_{2}=0\end{array}$} & \multicolumn{2}{|c|}{$\mathrm{O}_{2}$ partial pressure $(\mathrm{kPa})$} & \multirow{2}{*}{$\begin{array}{c}\mathrm{V}_{\mathrm{G}} \\
{[\%(\mathrm{v} / \mathrm{v})]}\end{array}$} & $\mathrm{O}_{2}^{\mathrm{y}}$ & $\mathrm{CO}_{2}$ \\
\hline & & Manometry & Devaux & & \multicolumn{2}{|c|}{$\left(\mathrm{mmol} \cdot \mathrm{kg}^{-1} \cdot \mathrm{h}^{-1}\right)$} \\
\hline & $17.02 \pm 0.40$ & $17.60 \pm 0.41$ & $16.75 \pm 0.41$ & $0.34 \pm 0.23$ & $0.117 \pm 0.005$ & $0.132 \pm 0.006$ \\
\hline Sweetpotato & $16.84 \pm 0.61$ & $18.71 \pm 0.69$ & $17.04 \pm 0.59$ & $8.57 \pm 0.44$ & $0.388 \pm 0.044$ & $0.413 \pm 0.040$ \\
\hline Tomato & $12.07 \pm 0.86$ & $13.62 \pm 1.1$ & $15.04 \pm 0.32$ & $6.41 \pm 0.8$ & $0.551 \pm 0.089$ & $0.544 \pm 0.031$ \\
\hline
\end{tabular}
volume $\left(\mathrm{V}_{\mathrm{G}}\right), \mathrm{O}_{2}$ consumption rate by manometry, and $\mathrm{CO}_{2}$ evolution rate by gas chromatography. These assays were performed at a barometric pressure of $91.2 \mathrm{kPa}$ at $11 \mathrm{C}$ for potatoes and sweetpotatoes and at $23 \mathrm{C}$ for tomatoes.

${ }^{\mathrm{z} E a c h}$ value represents mean of five replicates \pm sD.

${ }^{\mathrm{y} O x y g e n ~ c o n s u m p t i o n ~ r a t e s ~ a t ~ a n ~} \mathrm{O}_{2}$ partial pressure of $9.61 \mathrm{kPa}$. 


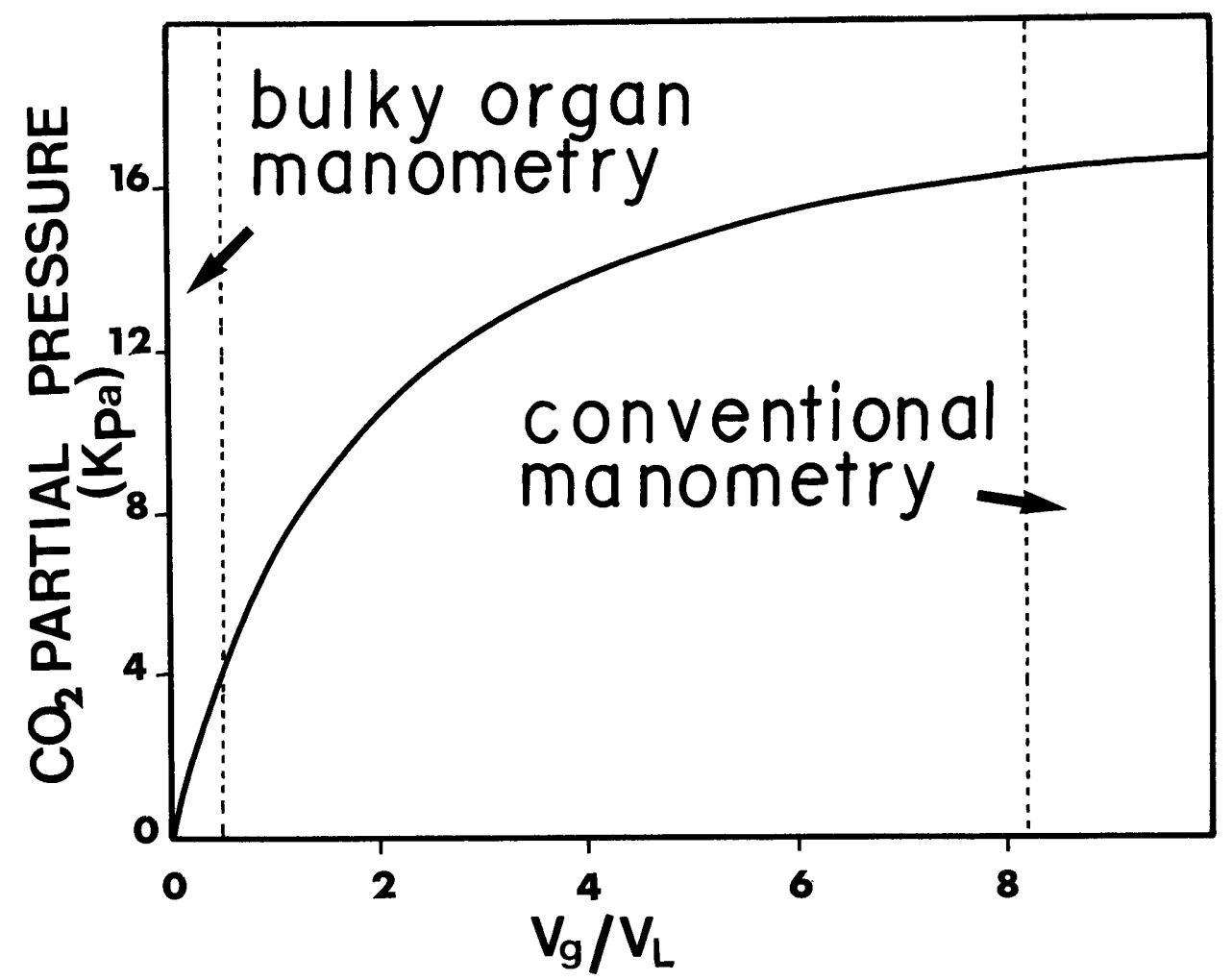

Fig. 4. Theoretical relationship between the $\mathrm{CO}_{2}$ partial pressure generated by $\mathrm{CO}_{2}$ evolution during the complete respiratory consumption of $\mathrm{O}_{2}$ as a function of the ratio between internal gas $\left(\mathrm{V}_{\mathrm{G}}\right)$ and volume $\left(\mathrm{V}_{\mathrm{L}}\right)$ of an organ according to Eq. [29].

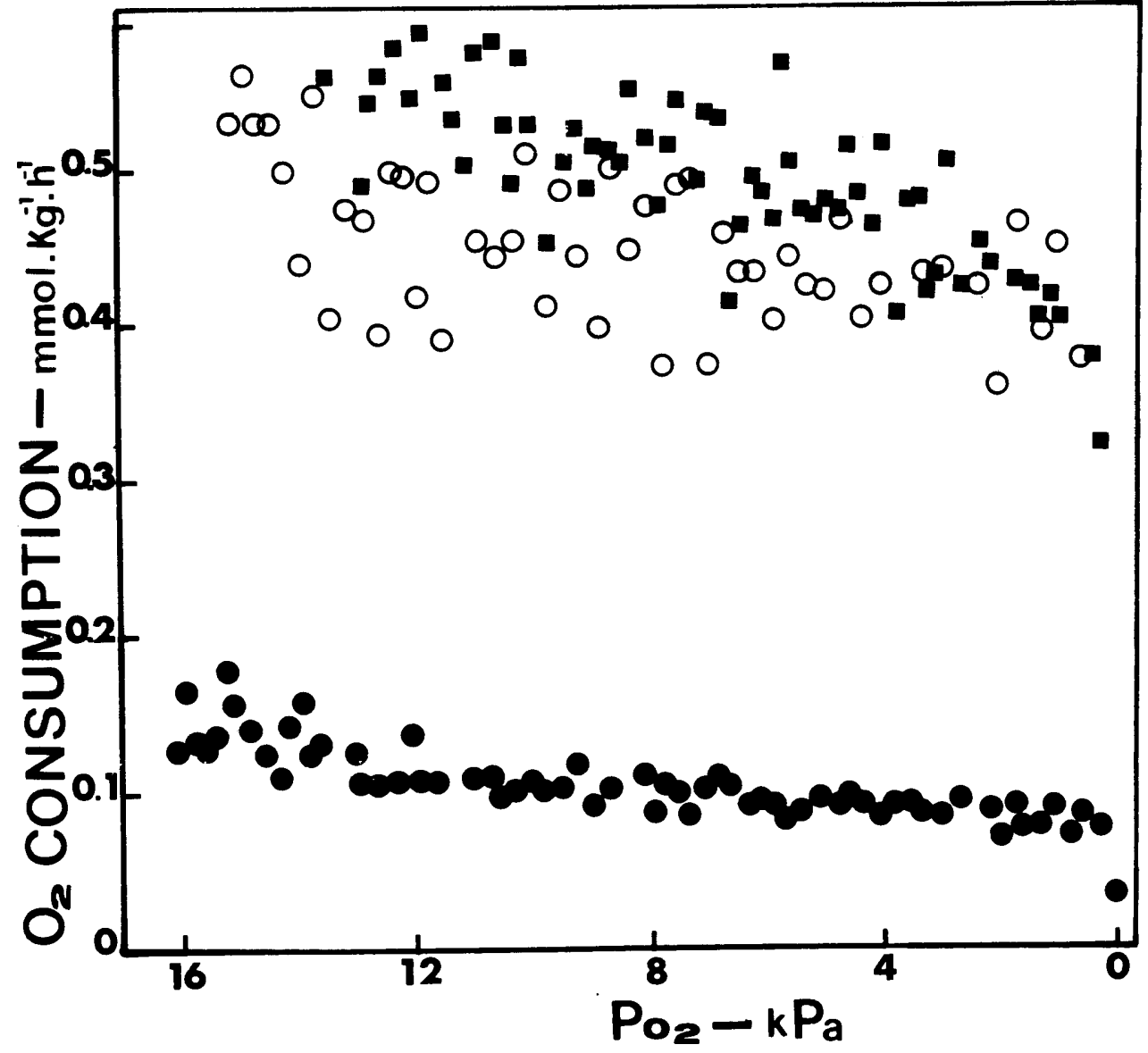

Fig. 5. Typical $\mathrm{O}_{2}$ consumption rates as a function of the internal $\mathrm{O}_{2}$ partial pressure $\left(\mathrm{P}_{\mathrm{O}_{2}}\right)$ reduction in potatoes $(\bullet)$ and sweetpotatoes $(\mathrm{O})$ at $11 \mathrm{C}$ and tomatoes $(\boldsymbol{\square})$ at $23 \mathrm{C}$ under a local barometric pressure of $91.2 \mathrm{kPa}$. 
phase. Potato, an organ that produces lactate instead of ethanol and $\mathrm{CO}_{2}$ in the absence of $\mathrm{O}_{2}$ (Beevers, 1961), had a $\mathrm{CO}_{2}$ evolution rate too low to be followed accurately in the anaerobic phase. A Michaelis-Menten least square fit for estimated $\mathrm{O}_{2}$ levels between $0 \%$ and $5 \%$ in Fig. 6a give a Km estimate of $0.0447 \pm 0.0100 \% \mathrm{O}_{2}$ $(\mathrm{n}=5)$ or $7.29 \mu \mathrm{M}$ of dissolved $\mathrm{O}_{2}$, a result that nearly agrees with that of Yocum and Hanckett (1957).

The presence of a dermal diffusion barrier can affect the shape of the curves relating internal $\mathrm{O}_{2}$ partial pressure and respiration, while the water manometer registers the initial $40 \mathrm{~cm}$ of pressure reduction. This fact was observed in potatoes (Fig. 6a), for which a rapid apparent respiratory reduction occurred in the first $20 \mathrm{~cm}$ of pressure reduction. In sweetpotatoes, the surface abrasion before the Devaux chamber attachment removed this initial error. For potato tubers, however, abrasion was not sufficient. In tomatoes, this error was not observed. If this anomaly occurs for any given organ, then the respiration estimates during the first $40 \mathrm{~cm}$ should be ignored.

The observed dead volume for the Devaux chamber, measured according to the required volume of petroleum jelly required to fill the space between the organ and the internal chamber surface, was $0.04 \mathrm{ml} ; \mathrm{n}=5$ was roughly similar to the potato $\mathrm{V}_{\mathrm{G}}$, from which $\mathrm{O}_{2}$ diffusion toward the organ could cause this initially rapid pressure reduction, a departure from the desired equilibrium. For organs with low intercellular air volume, this dead volume should be added to $\mathrm{V}_{\mathrm{G}}$, otherwise the respiration rate, according to Eqs. [14] and [27], will be underestimated.

There were near-linear relationships between time and the intercellular pressure inside a sweetpotato and a tomato (Figs. 6b, 7). Two factors may have caused a rapid transition from the nearlinear $\mathrm{O}_{2}$ consumption to the anaerobic $\mathrm{CO}_{2}$ evolution. First, the low $\mathrm{Km}$ value of the cytochrome oxidize was estimated to be

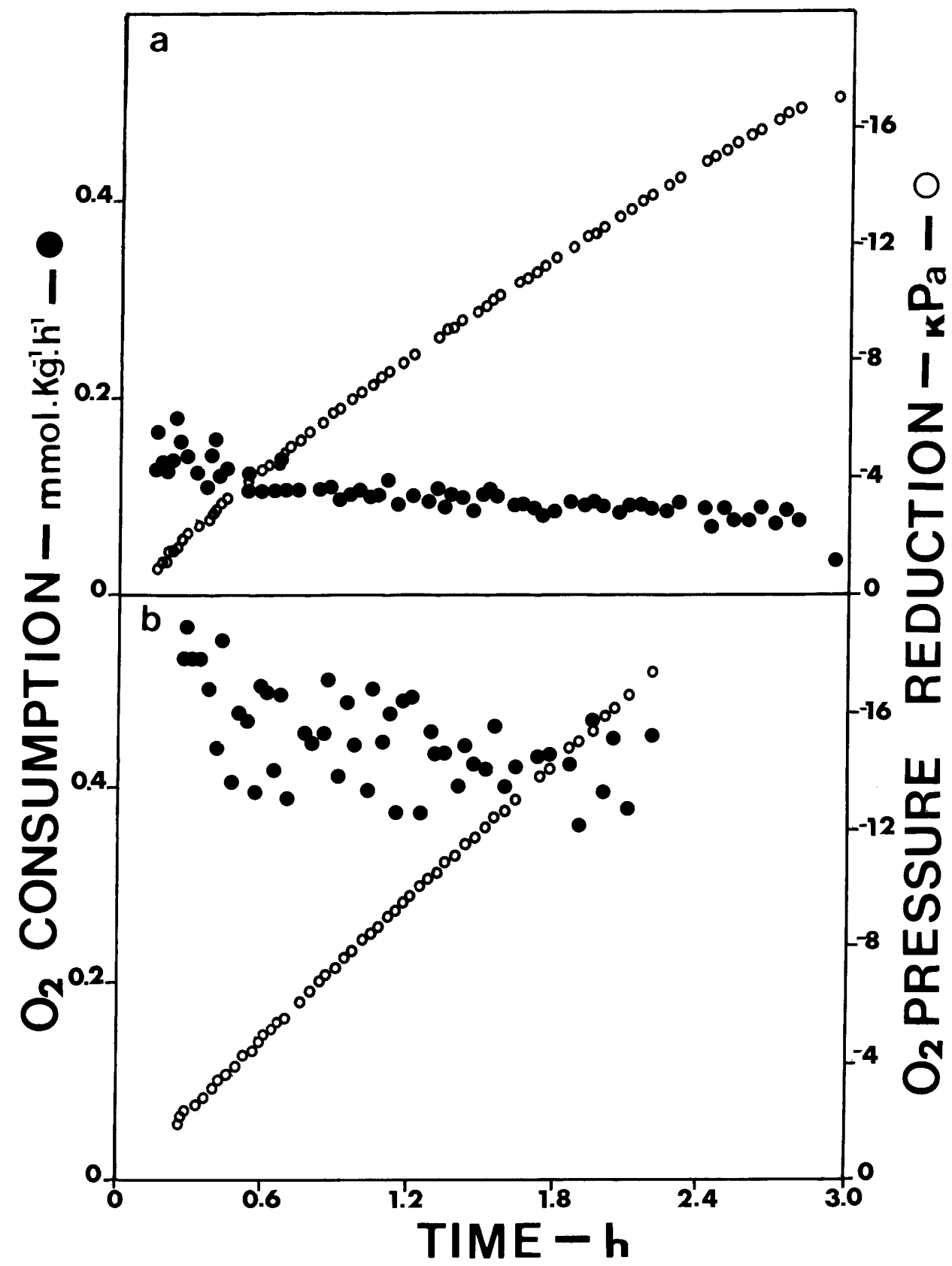

Fig. 6. Data obtained from bulk-organ constant-volume manometry applied to 'Bintje' potato tubers (a) and 'Coquinho' sweetpotato roots (b) at a barometric pressure of $91.2 \mathrm{kPa}$ at $11 \mathrm{C}$. Typical time-courses of the intercellular $\mathrm{O}_{2}$ pressure gradient $(\mathrm{O}) ; \mathrm{O}_{2}$ consumption as a function of time $(\bullet)$. 


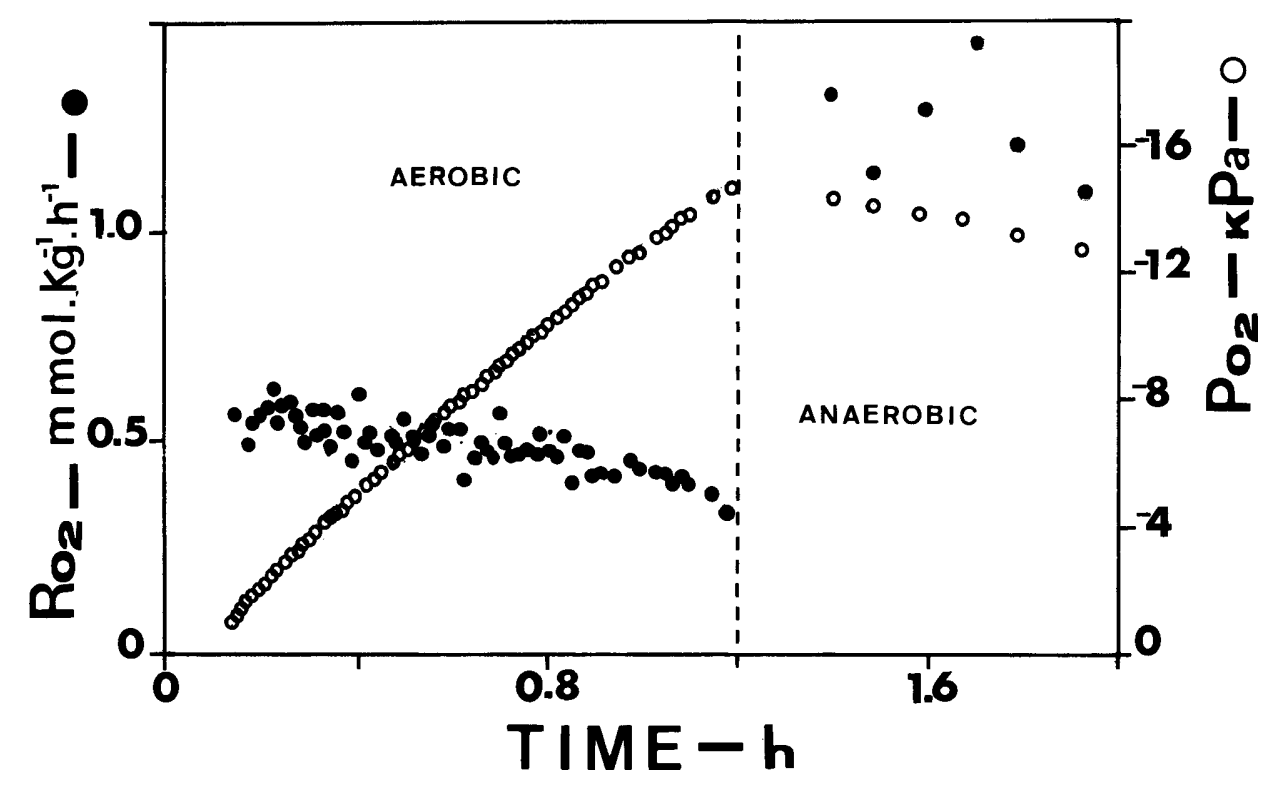

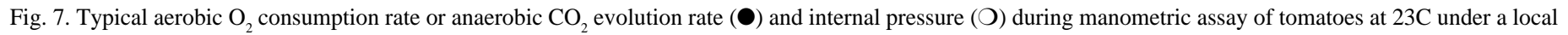
barometric pressure of $91.2 \mathrm{kPa}$.

$<0.091 \mathrm{kPa} \mathrm{O}_{2}$. Second, the plant tissues may require a near constant ATP supply and demand, possibly related to a rapid anaerobic respiration triggered as soon as the $\mathrm{O}_{2}$ was depleted.

The time spent to consume all of the $\mathrm{O}_{2}$ (Figs. $6 \mathrm{a}$ and $\mathrm{b}, 7$ ) was a function of the product's respiratory rate, temperature, and $\mathrm{V}_{\mathrm{G}}$. These periods were $\approx 1.5 \mathrm{~h}$ for sweetpotato and $3.5 \mathrm{~h}$ for potato, both at $11 \mathrm{C}$, and $0.5 \mathrm{~h}$ for tomato at $23 \mathrm{C}(\mathrm{n}=5)$. These long periods were considered experimentally desirable, since they allowed the required time for equilibrium between the liquid and gas phase.

Table 1 shows agreement between the estimates of the internal $\mathrm{O}_{2}$ pressure reduction by this constant-volume manometric technique and those obtained from gas samples taken from the Devaux (1891) external chamber. Small experimental differences between these methods, however, were conceivable since, besides the random experimental errors, at least the following factors were involved.

a) The plant intercellular air pressure usually is not in perfect equilibrium with the external atmosphere (Dancey, 1987). Gradients of 200 to $500 \mathrm{~Pa}$ were observed for sweetpotato roots at $11 \mathrm{C}$ and $90 \%$ relative humidity. For these observations, the manometer was connected to the organ using a Devaux chamber (Fig. 3).

b) The time before the beginning of the experiment, while the organ was being sealed, caused the largest differences in the tomatoes, since the connection of the Devaux chamber to the peduncle insertion nearly blocks fruit gas exchange.

c) There was some error in assessing the transition between aerobiosis and anaerobiosis ( $50 \mathrm{~Pa}$ ).

Constant-pressure manometry using the intercellular gas volume of bulky organs with very different $\mathrm{V}_{\mathrm{G}}$, anatomy, and morphology performed surprisingly well. The proposed method contrasts with Warburg-Bancroft constant-volume manometry, which uses an analogous set of equations derived for a chamber with a gas volume many times larger than the sample volume, and was specific for cells, tissue sections, or organs of very small dimensions (Perkins, 1943; Umbreit et al., 1972) with negligible diffusion resistance.

\section{Literature Cited}

Armstrong, W. 1979. Aeration in higher plants. Adv. Bot. Res. 7:225-232.

Beevers, H. 1961. Respiratory metabolism in plants. Fow Peterson, Lafayette, Ind.

Burk, D. and T. Milner. 1932. Microanalysis of gases in relation to organic and physiological chemistry. Ind. Eng. Chem. Anal. 4:3-7.

Burton, W.G. and W.T. Spragg. 1950. A note on the intercellular spaces of the potato tuber. New Phytol. 49:3-10.

Calbo, A.G. and A.A. Nery. 1994. Methods for measurement of gas volume of fruits and vegetables. J. Amer. Soc. Hort. Sci. (In press.)

Calbo, A.G. and N.F. Sommer. 1987. intercellular volume and resistance to mass air flow of fruits and vegetables. J. Amer. Soc. Hort. Sci. 112:131-34.

Cameron, A.C. 1982. Gas diffusion in bulky plant organs. PhD diss. Univ. of California, Davis.

Cameron, A.C. and S.F. Yang. 1982. A simple method for the determination of gas diffusion in plant organs. Plant Physiol. 70:21-23.

Dancey, J.W.M. 1987. Knudsen-transitional flow and gas pressurization in leaves of nelumbo. Plant Physiol. 85:199-203.

Devaux, H. 1891. Estude experimentale de I'aeration des tissues massifs. Introduction a l'etude exchanges gazeux chez les plantes aerennes. Ann. Sci. Nat. Bot. 14:279-295.

Jensen, C.R., R.J. Luxmore, S.D. Van Grundy, and L.H. Stolzy. 1969. Root air space measured by a pycnometer method. Agron. J. 61:474-475.

Magness, J.R. 1922. Composition of gases in intercellular spaces of apples and potatoes. Bot. Gaz. 13:349-57.

Nobel, P.S. 1970. Introduction to biophysical plant physiology. Freeman, San Francisco.

Perkins, J.J. 1943. Bancroft-Warburg manometric apparatus. Ind. Eng. Chem. Anal. Chem. 15:61-68.

Scholander, P.F. 1947. Analyzer for accurate estimation of respiratory gases in half cubic centimeter samples. J. Biol. Chem. 167:235-250.

Thoday, M.A. 1913. On the capillary eudimetric apparatus of Bonnier and Mangin for the analysis of air in investigating the gaseous exchanges of plants. Ann. Bot. 27:565-573.

Wardlaw, C.W. and E.R. Leonard. 1939. Studies in tropical fruits. IV. Methods in the investigation of respiration with special reference to the banana. Ann. Bot. 3:37-42.

Umbreit, W.W., R.H. Burris, and F.J. Stauffer. 1972. Manometric and biochemical techniques. 5th ed. Burgess, Minneapolis.

Yocum, C.S. and D.F. Hanckett. 1957. Participation of cytochromes in the respiration of the aroid spadix. Plant Physiol. 32:186-191. 